\title{
Ethanol in herbal medicinal products for children
}

\section{Data from pediatric studies and pharmacovigilance programs}

\author{
Olaf Kelber - Barbara Steinhoff · Christian Nauert - Andreas Biller · Martin Adler · Heba Abdel-Aziz • \\ Samuel N. Okpanyi · Karen Kraft · Karin Nieber
}

Received: 14 April 2015 / Accepted: 6 June 2016 / Published online: 28 July 2016

(C) The Author(s) 2016. This article is an open access publication.

Summary Herbal medicinal products are indispensable in children, e.g., in functional gastrointestinal diseases and coughs and colds, especially when available in liquid dosing forms for which dosing can be adapted ideally to different age groups. Despite being generally accepted as safe, the ethanol content of many of these products, necessary for Galenic reasons, has raised questions regarding their safety. Therefore, safety data from more than 50,000 children in noninterventional pediatric studies with these products, as well as data from routine clinical use in several million children, were assessed. No evidence of the involvement of the ethanol content in any adverse drug reactions was found. This allows us to conclude that these herbal medicinal products are safe in the age groups for which they are authorized or registered and that the present labeling is adequate to allow for their safe use in the pediatric population.

Keywords Pediatric medicinal product . Phytotherapy · Liquid dosing form · Labeling · Benefit-risk assessment

\section{O. Kelber · B. Steinhoff · C. Nauert · A. Biller · K. Kraft Board of the Corporative Members, Gesellschaft für Phytotherapie e.V. (GPT), Cologne, Germany}

\section{O. Kelber $(\bowtie)$}

Innovation \& Development, Phytomedicines Supply and Development Center, Bayer Consumer Health, Steigerwald Arzneimittelwerk GmbH, Havelstr. 5, 64295 Darmstadt, Germany

olaf.kelber@bayer.com

\section{B. Steinhoff}

Bundesverband der Arzneimittel-Hersteller, Bonn, Germany

C. Nauert

Cassella-med GmbH \& Co. KG, Cologne, Germany

\author{
A. Biller \\ Dr. Loges + Co. GmbH, Winsen, Germany
}

Ethanol in pflanzlichen Arzneimitteln für Kinder Daten aus pädiatrischen Studien und der RoutinePharmakovigilanz

Zusammenfassung Pflanzliche Arzneimittel gehören bei Kindern zum unverzichtbaren Arzneimittelschatz, beispielsweise bei funktionellen gastrointestinalen Erkrankungen sowie Husten und Erkältung. Dies trifft insbesondere auf flüssige Darreichungsformen zu, bei denen die Dosierung ideal an unterschiedliche Altersgruppen angepasst werden kann. Obwohl sie generell als sehr sicher gelten, wirft der Alkoholgehalt vieler dieser Arzneimittel, der aus galenischen Gründen notwendig ist, immer wieder Fragen auf. Daher wurden Sicherheitsdaten von über 50.000 Kindern aus nichtinterventionellen Studien (NIS) sowie aus der Routine-Pharmakovigilanz bei Arzneimitteln, die an mehreren Millionen Kindern angewendeten wurden, ausgewertet. Es wurden keine Hinweise auf durch den Al-

M. Adler

Institute for Integrative Medicine Siegen, Siegen, Germany

H. Abdel-Aziz · S. N. Okpanyi

Medical Affairs, Phytomedicines Supply and Development

Center , Bayer Consumer Health, Steigerwald

Arzneimittelwerk GmbH , Darmstadt, Germany

K. Kraft

Chair of Complementary Medicine, Center of Internal

Medicine, Universitätsmedizin Rostock, Rostock, Germany

K. Nieber

Scientific Board, Gesellschaft für Phytotherapie e. V. (GPT), Cologne, Germany

Institute of Pharmacy, University of Leipzig, Leipzig, Germany 
koholgehalt bedingte Nebenwirkungen gefunden. Daraus lässt sich schließen, dass diese pflanzlichen Arzneimittel in allen Altersgruppen, für welche sie zugelassen oder registriert sind, gefahrlos angewendet werden können, und dass die gegenwärtigen Texte in Fach- und Gebrauchsinformationen eine unbedenkliche Anwendung bei Kindern sicherstellen.

Schlüsselwörter Kinderarzneimittel · Phytotherapie · Flüssige Darreichungsform · Fach- und Gebrauchsinformation · Nutzen-Risiko-Bewertung

\section{Introduction}

Ethanol is a component of many herbal fluid preparations [1], since it is an excellent solvent for the extraction of herbal drugs and contributes to the stability of these medicines. Toxicological and pharmacokinetic evaluations have shown that the small amounts of ethanol applied with therapeutic doses are safe even in children [2, 3], while for potential surrogate solvents, e.g., glycerol or propylene glycol, toxicological proof of safety is not equally convincing $[3,4]$. Typical doses of herbal medicines for children aged 6-12 years contain $0.07-0.18$ g ethanol, which is equivalent to, e. g., 31-75 ml of apple juice (with an ethanol content of $0.3 \%$ ), and is eliminated from the blood within 1-3 min. These doses lead to a maximum blood ethanol content of $0.008-0.015 \mathrm{~g} / \mathrm{l}$, calculated under assumption of the worst case scenario.
Regulations in Germany [5] require a warning label if an adult single dose contains $0.5 \mathrm{~g}$ or more of ethanol and this also applies to lower doses of the same product for children. The French view [6] allows an ethanol content per single dose leading to a blood ethanol concentration not greater than $0.125 \mathrm{~g} / \mathrm{l}$. More recently, a draft for a Q \& A paper of the European Medicines Agency (EMA) [7] was published. There, a warning is issued for a single dose of $6 \mathrm{mg} / \mathrm{kg}$ or more (this is equivalent to a dose of $120 \mathrm{mg}$ ethanol or $50 \mathrm{ml}$ apple juice in a 6-year-old with a body weight of $20 \mathrm{~kg}$ ), stating that in children aged 6 years and younger, drowsiness, behavioral changes, and impaired ability to concentrate and participate in school activities can occur.

Given the different regulatory approaches, and against the background of public discussions triggered by the problem of recreational misuse of alcoholic beverages by adolescents [8-10], there is a need for a systematic evaluation of clinical and pharmacovigilance data on herbal medicines containing ethanol for children.

\section{Materials and methods}

In the pharmacovigilance system in Germany, all reports of adverse drug reactions (ADRs) on herbal medicinal products in Germany are collected by the manufacturers. Line listings and data from periodic safety update reports (PSURs) on ADRs for herbal

Table 1 Studies with herbal medicinal products in children (in alphabetical order)

\begin{tabular}{|c|c|c|c|c|c|c|}
\hline Herbal medicinal product & Number and age of children evaluated & Dose & $\begin{array}{l}\%(v / v) \\
\text { ethanol }\end{array}$ & $\begin{array}{l}\text { Gram ethanol } \\
\text { per dose }^{b}\end{array}$ & References & $\mathrm{ADR}^{\mathrm{a}}$ \\
\hline \multirow{2}{*}{$\begin{array}{l}\text { Bronchicum }{ }^{\circledR} \text { Elixir, oral } \\
\text { liquid }\end{array}$} & $n=312$ children ( $1-4$ years) & $2.5 \mathrm{ml} 6 \times$ daily & \multirow[t]{2}{*}{4.9} & 0.097 & \multirow[t]{2}{*}{ [14-16] } & \multirow[t]{2}{*}{3} \\
\hline & $n=324$ children ( $5-12$ years) & $5.0 \mathrm{ml} 6 \times$ daily & & 0.194 & & \\
\hline \multirow{2}{*}{$\begin{array}{l}\text { Bronchicum }{ }^{\circledR} \text { Elixir, oral } \\
\text { liquid }\end{array}$} & $n=111$ children $(1-4$ years $)$ & $2.5 \mathrm{ml} 6 \times$ daily & \multirow[t]{2}{*}{4.9} & 0.097 & \multirow[t]{3}{*}[16,17]{$^{d}$} & \multirow[t]{2}{*}{0} \\
\hline & $n=109$ children ( $5-12$ years) & $5.0 \mathrm{ml} 6 \times$ daily & & 0.194 & & \\
\hline $\begin{array}{l}\text { Bronchicum }{ }^{\circledR} \text { Tropfen, oral } \\
\text { liquid }\end{array}$ & $n=110$ school children (6-12 years ) & 25 drops $5 \times$ daily & $27.7^{c}$ & 0.274 & & 0 \\
\hline \multirow{2}{*}{$\begin{array}{l}\text { Bronchicum }{ }^{\circledR} \text { Elixir, oral } \\
\text { liquid }\end{array}$} & $n=474$ children ( $1-4$ years) & $2.5 \mathrm{ml} 6 \times$ daily & \multirow[t]{2}{*}{4.9} & 0.097 & \multirow[t]{2}{*}[18,19]{} & \multirow[t]{2}{*}{3} \\
\hline & $n=365$ children ( $5-12$ years $)$ & $5.0 \mathrm{ml} 6 \times$ daily & & 0.194 & & \\
\hline $\begin{array}{l}\text { Bronchicum }{ }^{\circledR} \text { Elixir, oral } \\
\text { liquid }\end{array}$ & $n=200$ infants (6-12 months) & $1.0 \mathrm{ml} 6 \times$ daily & 4.9 & 0.039 & {$[20,21]^{d}$} & 1 \\
\hline \multirow{3}{*}{$\begin{array}{l}\text { Contramutan }{ }^{\circledR} \text { Tropfen, oral } \\
\text { liquid }\end{array}$} & $n=85$ infants (6-12 months) & 2-3 drops $12 \times$ daily & \multirow[t]{3}{*}{$33.4^{\mathrm{C}}$} & 0.040 & \multirow[t]{6}{*}{ [12] } & \multirow[t]{3}{*}{0} \\
\hline & $n=95$ children ( $1-6$ years) & $3-5$ drops $12 \times$ daily & & 0.066 & & \\
\hline & $n=90$ school children (6-12 years) & 4-7 drops $12 \times$ daily & & 0.092 & & \\
\hline \multirow{3}{*}{$\begin{array}{l}\text { Contramutan }{ }^{\circledR} \text { Saft, oral } \\
\text { liquid }\end{array}$} & $n=174$ infants (6-12 months) & $1.5-2.0 \mathrm{ml} 12 \times$ daily & \multirow[t]{3}{*}{3.6} & 0.057 & & \multirow[t]{3}{*}{0} \\
\hline & $n=195$ children $(1-6$ years $)$ & $2.0-3.5 \mathrm{ml} 12 \times$ daily & & 0.100 & & \\
\hline & $n=188$ school children (6-12 years) & $3.0-5.0 \mathrm{ml} 12 \times$ daily & & 0.142 & & \\
\hline \multirow{3}{*}{$\begin{array}{l}\text { Contramutan }{ }^{\circledR} \text { Saft, oral } \\
\text { liquid }\end{array}$} & $n=100$ infants (6-12 months) & $2.0 \mathrm{ml} 12 \times$ daily & \multirow[t]{3}{*}{3.6} & 0.057 & \multirow[t]{3}{*}[22]{$^{d}$} & \multirow[t]{3}{*}{0} \\
\hline & $n=100$ children $(1-6$ years $)$ & $4.0 \mathrm{ml} 12 \times$ daily & & 0.114 & & \\
\hline & $n=100$ school children (7-12 years) & $5.0 \mathrm{ml} 12 \times$ daily & & 0.142 & & \\
\hline \multirow[t]{4}{*}{ lberogast ${ }^{\circledR}$, oral liquid } & $n=642$ infants (under 3 months) & $0.33 \mathrm{ml} 3 \times$ daily & \multirow[t]{4}{*}{$31.0^{c}$} & 0.081 & \multirow[t]{4}{*}[23]{} & \multirow[t]{4}{*}{0} \\
\hline & $n=7709$ infants (3 months- 3 years) & $0.4 \mathrm{ml} 3 \times$ daily & & 0.098 & & \\
\hline & $n=12,802(4-6$ years $)$ & $0.5 \mathrm{ml} 3 \times$ daily & & 0.122 & & \\
\hline & $n=19,808(7-12$ years $)$ & $0.75 \mathrm{ml} 3 \times$ daily & & 0.184 & & \\
\hline
\end{tabular}


Table 1 (Continued)

\begin{tabular}{|c|c|c|c|c|c|c|}
\hline Herbal medicinal product & Number and age of children evaluated & Dose & $\begin{array}{l}\%(v / v) \\
\text { ethanol }\end{array}$ & $\begin{array}{l}\text { Gram ethanol } \\
\text { per dose }\end{array}$ & References & $\mathrm{ADR}^{\mathrm{a}}$ \\
\hline \multirow[t]{4}{*}{ Iberogast ${ }^{\circledR}$, oral liquid } & $n=13$ infants (under 3 months) & $0.33 \mathrm{ml} 3 \times$ daily & \multirow[t]{4}{*}{$31.0^{c}$} & 0.081 & \multirow[t]{4}{*}{ [24] } & \multirow[t]{4}{*}{0} \\
\hline & $n=286$ infants (3 month -3 years) & $0.4 \mathrm{ml} 3 \times$ daily & & 0.098 & & \\
\hline & $n=480$ children (4-6 years) & $0.5 \mathrm{ml} 3 \times$ daily & & 0.122 & & \\
\hline & $n=1571$ school children ( $7-12$ years) & $0.75 \mathrm{ml} 3 \times$ daily & & 0.184 & & \\
\hline \multirow[t]{2}{*}{ Iberogast ${ }^{\circledR}$, oral liquid } & $n=389$ children (3-6 years) & $0.5 \mathrm{ml} 3 \times$ daily & \multirow[t]{2}{*}{$31.0^{\mathrm{C}}$} & 0.122 & \multirow[t]{2}{*}{ [25] } & \multirow[t]{2}{*}{4} \\
\hline & $n=591$ school children (7-14 years) & $0.75 \mathrm{ml} 3 \times$ daily & & 0.184 & & \\
\hline \multirow[t]{3}{*}{ Monpax ${ }^{\circledR}$ Saft, oral liquid } & $\begin{array}{l}n=118 \text { infants }(7-12 \text { months })+\text { infants } \\
(1-3 \text { years })\end{array}$ & $2.5 \mathrm{ml} 3 \times$ daily & \multirow[t]{3}{*}{3.9} & 0.077 & \multirow[t]{6}{*}{ [26] } & \multirow[t]{3}{*}{0} \\
\hline & $n=119$ children ( $4-7$ years) & $2.5 \mathrm{ml} 4 \times$ daily & & 0.077 & & \\
\hline & $n=113$ school children (8-14 years) & $5.0 \mathrm{ml} 3 \times$ daily & & 0.154 & & \\
\hline \multirow[t]{3}{*}{$\begin{array}{l}\text { Monapax }{ }^{\circledR} \text { Tropfen, oral } \\
\text { liquid }\end{array}$} & $\begin{array}{l}n=118 \text { infants ( } 7-12 \text { months) }+ \text { infants } \\
\text { (1-3years) }\end{array}$ & 8 drops $3 \times$ daily & \multirow[t]{3}{*}{$32.8^{\mathrm{C}}$} & 0.104 & & \multirow[t]{3}{*}{0} \\
\hline & $n=115$ children (4-7 years) & 10 drops $3 \times$ daily & & 0.130 & & \\
\hline & $n=115$ school children (8-14 years) & 10 drops $4 \times$ daily & & 0.130 & & \\
\hline \multirow{3}{*}{$\begin{array}{l}\text { Phytohusti|® Hustenreizstiller } \\
\text { Sirup, oral liquid }\end{array}$} & $n=100$ children (under 3 years) & $2.5-3 \mathrm{ml} 4 \times$ daily & \multirow[t]{3}{*}{1.1} & 0.026 & \multirow[t]{3}{*}{ [27] } & \multirow[t]{3}{*}{0} \\
\hline & $n=115$ children $(3-6$ years $)$ & $5 \mathrm{ml} 4 \times$ daily & & 0.043 & & \\
\hline & $n=98$ school children (6-12 years) & $5 \mathrm{ml} 5 \times$ daily & & 0.043 & & \\
\hline \multirow{4}{*}{$\begin{array}{l}\text { Phytohusti|® Hustenreizstiller } \\
\text { Sirup, oral liquid }\end{array}$} & $n=61$ infants (under 3 months) & $2.5 \mathrm{ml} 4 \times$ daily & \multirow[t]{4}{*}{1.1} & 0.022 & \multirow[t]{4}{*}[28]{$^{d}$} & \multirow[t]{4}{*}{0} \\
\hline & $n=128$ infants ( 3 month to 2 years) & $3.4 \mathrm{ml} 4 \times$ daily & & 0.030 & & \\
\hline & $n=188$ children ( $3-5$ years) & $4.3 \mathrm{ml} 4 \times$ daily & & 0.037 & & \\
\hline & $n=222$ school children (6-12 years) & $4.6 \mathrm{ml} 5 \times$ daily & & 0.040 & & \\
\hline \multirow{4}{*}{$\begin{array}{l}\text { Phytobronchin }{ }^{\circledR} \text { Saft S } \\
\text { Lösung, oral liquid }\end{array}$} & $n=220$ infants (under 1 year) & $2.5 \mathrm{ml} 3 \times$ daily & \multirow[t]{4}{*}{$5.0-8.0$} & 0.158 & \multirow[t]{4}{*}{ [29] } & \multirow[t]{4}{*}{4} \\
\hline & $n=267$ children (1-2 years) & $3 \mathrm{~m} 3 \times$ daily & & 0.190 & & \\
\hline & $n=352$ children ( $3-5$ years) & $5 \mathrm{ml} 3 \times$ daily & & 0.316 & & \\
\hline & $n=401$ school children (6-12 years) & $5 \mathrm{ml} 3-4 \times$ daily & & 0.316 & & \\
\hline \multirow{3}{*}{$\begin{array}{l}\text { Soledum }{ }^{\circledR} \text { Hustensaft, oral } \\
\text { liquid }\end{array}$} & $n=18$ infants (under 2 years) & $1.25 \mathrm{ml} \mathrm{3-4} \times$ daily & \multirow[t]{3}{*}{5.8} & 0.057 & \multirow[t]{3}{*}{-} & \multirow[t]{3}{*}{0} \\
\hline & $n=105$ children ( $2-6$ years) & $2.5 \mathrm{ml} \mathrm{3-4} \times$ daily & & 0.115 & & \\
\hline & $n=19$ school children (7-10 years) & $5 \mathrm{ml} \mathrm{3-4} \times$ daily & & 0.229 & & \\
\hline Sum & $n=50,316$ children ( $0-12$ years) & - & - & - & - & 15 \\
\hline
\end{tabular}

medicinal products up to 2009 containing ethanol were provided by manufacturers and assessed by the authors regarding a potential causality between the reports and the ethanol content of the medicines. For the same medicines, sales figures for Germany from IMS Health GmbH, Frankfurt/Main, Germany, were provided for the years 2005-2009, separately for total sales and sales prescribed by physicians and reimbursed by the health insurance. These Rx figures represent mainly prescriptions to children, as these medicines are reimbursed in Germany only for children up to 12 years of age and for adolescents up to 18 years of age with developmental disturbances (according to $\S 34$, paragraph 1, No 1 and 2, Sozialgesetzbuch V, Germany) but they are not reimbursed in adults. Total sales figures (according to PSUR data) provided by the manufactures are given as daily doses (assuming adult doses for precautionary reasons) and patient numbers, assuming a treatment duration of 4 weeks.
In addition, all clinical studies in children available for these medicines were collected and the numbers of children and adults included as well as the ethanol doses corresponding to a single dose were listed. Studies available from congress abstracts or company reports are listed in Table 1. Single dose, daily dose, and ethanol content are according to information in the AMIS database accessible via DIMDI, Bonn, Germany. Ethanol content is given per single dose, as the small amounts of ethanol applied per single dose are metabolized within seconds or minutes so that dosing according to the therapeutic dosing schedule cannot lead to an accumulation [4]. Numbers of ADRs were listed and it was evaluated whether they were attributable to the ethanol content of the medicinal products. 
Table 2 Safety data for some herbal medicinal products containing ethanol ${ }^{\mathrm{a}}$

\begin{tabular}{|c|c|c|c|c|}
\hline Herbal medicinal product & Period & $\begin{array}{l}\text { Daily doses sold ( } n \\
\text { million) }\end{array}$ & $\begin{array}{l}\text { Corresponding number of pa- } \\
\text { tients }(n \text {, million) }\end{array}$ & $\begin{array}{l}\text { ADRs attributable to } \\
\text { ethanol }\end{array}$ \\
\hline Allergo-loges ${ }^{\circledR}$ & 2003-2009 & 3.4 & 0.1 & None \\
\hline Bronchicum ${ }^{\circledR}$ Elixir & 2004-2009 & 19.3 & 1.6 & None \\
\hline Bronchicum ${ }^{\circledR}$ Tropfen & 2004-2009 & 47.8 & 4.0 & None \\
\hline Contramutan ${ }^{\circledR}$ N Saft & 2004-2009 & 4.8 & 0.4 & None \\
\hline Contramutan ${ }^{\circledR}$ Tropfen & 2004-2009 & 2.1 & 0.2 & None \\
\hline Diarrhoesan ${ }^{\circledR}$ & 2003-2009 & 4.4 & 0.6 & None \\
\hline Iberogast ${ }^{\circledR}$ & 1993-2009 & 636.9 & 22.7 & None \\
\hline Influex ${ }^{\circledR}$ & 1993-2009 & 15.5 & 1.5 & None \\
\hline Melrosum ${ }^{\circledR}$ Hustensirup & 2004-2009 & 2.1 & 0.2 & None \\
\hline Monapax ${ }^{\circledR}$ Saft & 2004-2009 & 7.2 & 0.6 & None \\
\hline Monapax ${ }^{\circledR}$ Tropfen & 2004-2009 & 1.5 & 0.1 & None \\
\hline Phytobronchin ${ }^{\circledR}$ Saft S Lösung & 1994-2009 & 3.4 & 0.4 & None \\
\hline Phytohusti| ${ }^{\circledR}$ Hustenreizstiller Sirup & 2000-2009 & 11.4 & 1.4 & None \\
\hline Soledum ${ }^{\circledR}$ Hustensaft & 2004-2009 & 3.5 & 0.3 & None \\
\hline Soledum ${ }^{\circledR}$ Hustentropfen & 2004-2009 & 1.3 & 0.1 & None \\
\hline Total & & 764.6 & 34.3 & None \\
\hline
\end{tabular}

Table 3 Sales figures of some herbal medicinal products containing ethanol

\begin{tabular}{|l|l|l|}
\hline Product & $\begin{array}{l}\text { Sales figures total } \\
\text { (million packages) }\end{array}$ & $\begin{array}{l}\text { Sales figures Rx } \\
\text { (million packages) }\end{array}$ \\
\hline $2005-9 / 2009$ & 2005 -9009 \\
\hline Bronchicum ${ }^{\circledR}$ Elixir & 8.23 & 2.22 \\
\hline Bronchicum ${ }^{\circledR}$ Tropfen & 5.81 & 0.58 \\
\hline Contramutan ${ }^{\circledR}$ Saft & 3.16 & 1.52 \\
\hline Contramutan ${ }^{\circledR}$ Tropfen & 0.90 & 0.18 \\
\hline Melrosum ${ }^{\circledR}$ Sirup & 0.74 & 0.40 \\
\hline Monapax ${ }^{\circledR}$ Saft & 2.69 & 1.51 \\
\hline Monapax ${ }^{\circledR}$ Tropfen & 0.31 & 0.13 \\
\hline Soledum ${ }^{\circledR}$ Hustensaft & 1.410 & 0.48 \\
\hline Soledum ${ }^{\circledR}$ Tropfen & 0.17 & 0.05 \\
\hline Diarrhoesan ${ }^{\circledR}$ & 1.04 & 0.58 \\
\hline Toxi-loges ${ }^{\circledR}$ Tropfen & 0.77 & 0.02 \\
\hline Alergo-Ioges ${ }^{\circledR}$ & 0.05 & 0.00 \\
\hline Iberogast ${ }^{\circledR}$ & 20.63 & 2.86 \\
\hline Phytohusti| ${ }^{\circledR}$ Hustenreizstiller & 1.44 & 0.17 \\
\hline Sirup & & 0.07 \\
\hline Phytobronchin ${ }^{\circledR}$ Saft S Lösung & 0.41 & 0.09 \\
\hline Phytodolor ${ }^{\circledR}$ & 0.29 & 10.85 \\
\hline Sum & 48.09 & \\
\hline & & \\
\hline
\end{tabular}

\section{Results}

\section{Data from clinical studies}

For an evaluation of the experience gained from the therapeutic use of these medicines, 17 prospective and retrospective studies with ten herbal medicinal products were analyzed, containing ethanol at doses of 0.022-0.274 g per single application, depending on the age group. These studies cover 50,316 children of 0-12 years of age (Table 1). In these studies, altogether 15 ADRs have been described, none of which was attributable to the ethanol content of the medicines. The inclusion of three studies comprising 1041 children solely documented in congress abstracts or internal reports submitted to regulatory authorities does not change this picture.

\section{Pharmacovigilance data and patient exposure}

Of the medicinal products listed in Table 1 and six additional medicinal products containing ethanol, during the period from 2005 to 2009 more than 764 million daily doses were sold, which corresponds to more than 33 million patients (Table 2).

From the packages of these medicines sold in Germany between 2005 and 2009, 48.1 million were sold over the counter, of which 10.8 million prescriptions were covered by health insurance (Table 3 ). The latter can be assumed to have been used in children by about $90 \%$.

ADRs in these medicines are covered by the pharmacovigilance system, as mentioned earlier, and no ADRs attributable to the ethanol content have been reported.

\section{Discussion}

There is a wide use of herbal medicinal products containing small amounts of ethanol, in the range between 0.022 and $0.274 \mathrm{~g}$ per single dose, depending on the respective medicinal product and the different age groups. These doses are clearly within the range of ethanol doses given to children with normal food and 
drinks accepted as safe in this age group, for example, a typical serving of apple juice $(100 \mathrm{ml})$ is expected to have $0.240 \mathrm{~g}$ ethanol [4]. Liquid dosage forms have an advantage for use in children, as it is possible to adapt doses to the respective age groups. Ethanol is specified as the extraction solvent for herbal medicinal products in all relevant pharmacopeias, and replacement by other solvents like glycerol or propylene glycol and by the addition of preservatives is not generally applicable, as the toxicological proof of safety for these substances is not equally convincing $[4,11]$. Therefore these medicines are rated as safe for use in children by regulatory agencies and are also perceived as safe by health professionals and consumers [2]. The data presented here give strong support to these ratings.

The use of these medicines is very widespread: During the period 1993/2004-2009, more than 700 million daily doses were sold, which can be assumed to correspond to more than 30 million patients taking these medicinal products. Even when assuming that, for example, $50 \%$ of the doses sold are not used (which is likely to be highly exaggerated in the case of OTC products paid by the patients themselves and indicated in frequently occurring diseases such as coughs and colds and functional gastrointestinal diseases), these figures are impressive, given that no ADRs attributable to ethanol have been reported.

According to Table 3, about $20 \%$ of the 50 million packages of these medicinal products sold within this 5 -year period can be assumed to have been prescribed to children. Thus, about three million children (given very conservative assumptions probably significantly underestimating the real figures) can be assumed to be included in the overall patient figures given, underlining the relevance of the conclusions to children.

From studies, i. e., from therapeutic use controlled by physicians, the use of these products in more than 50,000 children of different age groups is documented. The studies differed in design (retro- and prospective noninterventional studies, NIS), which can be assumed to be the cause of the different figures of ADRs per patient, with prospective studies usually generating higher figures; however, it can also be assumed that no serious or otherwise significant side effects would have been missed by the physicians involved. In this survey, all available evidence is included, also taking into account congress abstracts and internal reports submitted to regulatory authorities, as they add to the overall picture and are in line with the other studies, apparently without introducing a bias. The number of ADRs is overall low, and their analysis resulted in the conclusion that they do not involve any effects potentially related to the ethanol content of the medicinal products.

The data presented here are in accordance with the conclusions drawn from data on the ADME of ethanol and the commonly accepted ethanol uptake in children with their usual nutrition [4], which is far below doses that could lead to pharmacological or toxicological effects. This also applies to the case of a study in which single doses corresponding to $142 \mathrm{mg}$ ethanol were applied to children between 6 and 12 years up to 12 times per day [12], as this single dose of ethanol is eliminated within 3 min [4] so that an accumulation is not to be expected. That relevant blood ethanol levels are not achieved has recently also been confirmed by a pharmacokinetic study with one of the medicinal products included in this review, Bronchicum ${ }^{\circledR}$ Elixir [11], where children of 1-12 years of age were included. Therefore, there is no specific risk to be assigned to the ethanol content of these medicines. The ethanol content consequently does not have a relevant impact on the benefit-risk assessment of these medicines in children. This applies likewise to products with a marketing authorization based on a clinical proof of efficacy and to products registered according to EU regulations [13] based on their traditional use, as these products may also not be harmful in the specified conditions of use and their efficacy needs to be plausible on the basis of long-standing use and experience.

Therefore, the texts in the summary of the product characteristics of these products, such as those in accordance with the present regulations in Germany, which in most products only state the percentage of ethanol content in the solution [5], are appropriate, and any further texts or warnings would suggest a risk that is not relevant and could therefore be misleading.

\section{Conclusion}

The data on pharmacokinetics, pharmacodynamics, and toxicology confirm the long-standing experience with herbal medicinal products, according to which the ethanol content of these products, such as those presently authorized or registered in EU countries, does not give cause for concern regarding their safety in children. The data do not support adding warning labels that apply to doses in the range of or even below those found in usual nutrition that is accepted as safe in children. The regulation already in force today for these products is therefore fully in accordance with the present scientific and medicinal state of the art.

Acknowledgements This contribution is dedicated, on the occasion of his 85th birthday, to Prof. Dr. Dr. h. c. mult. Heinz Schilcher, Immenstadt/Bayern, Germany, who to our great regret deceased on 17 June 2015. His textbook Leitfaden Phytotherapie gives an excellent summary of the subject of ethanol in herbal medicinal products for children.

Conflict of interest O. Kelber, B. Steinhoff, C. Nauert, A. Biller, H. Abdel-Aziz, and S.N. Okpanyi are or were employees of pharmaceutical companies or industry associations. M. Adler, K. Kraft, and K. Nieber have received research grants from pharmaceutical companies. 
Open Access This article is distributed under the terms of the Creative Commons Attribution 4.0 International License (http://creativecommons.org/licenses/by/4.0/), which permits unrestricted use, distribution, and reproduction in any medium, provided you give appropriate credit to the original author(s) and the source, provide a link to the Creative Commons license, and indicate if changes were made.

\section{References}

1. Schilcher H, Dorsch W. Phytotherapie in der Kinderheilkunde. Stuttgart: Wissenschaftliche Verlagsgesellschaft; 2006.

2. Schilcher H, Kammerer S, Wegener T. Leitfaden Phytotherapie. München: Urban \& Fischer; 2010.

3. Kauert G. Sind ethanolhaltige Phytopharmakazubereitungen in der Pädiatrie toxikologisch bedenklich? Phytopharmaka. 1998;4:95-100.

4. Kelber O, Gaedcke F, Steinhoff B, et al. Ethanol in herbal medicinal products for children. Pharma Ind. 2008;70(9):1124-7.

5. Bundesministerium der Justiz und für Verbraucherschutz. Arzneimittel-Warnhinweisverordnung vom 21. Dezember 1984, BGBl. 1985Ip22.

6. Comite de coordination de toxicovigilance. Avis sur le seuil d'éthanol dans les solutions buvables administrées à l'enfant, rapport fait à la demande de l'Afssaps, Décembre 2006, Direction de l'evaluation des medicaments et des produits biologiques.

7. Committee for Human Medicinal Products of EMA. Questions andAnswers onEthanolinthe context of therevision of the guideline on Excipients in the label and package leaflet of medicinal products for human use (CPMP/463/00) of 23 January 2014. London; 2014.

8. LockemannU,PüschelK.Alkoholvergiftungim Kindesalter. Päd 1996;2:92-8.

9. HMPC. Reflection paper on ethanol content in herbal medicinal products and traditional herbal medicinal products used in children. EMA/HMPC/85114/2008. 2010.

10. N.N. Bestandsmarkt unter der Lupe. G-BA unterzieht sechs Wirkstoffgruppen der Prüfung. Dtsch Apoth Ztg. 2013;153(17):32-3.

11. Ludwig S, Stier H, Weykam S. Evaluation of blood alcohol concentrations after oral administration of a fixed combination of thyme herb and primrose root fluid extract to children with acute bronchitis. Drug Res. 2015;66(2):69-73. doi:10.1055/s-0034-1398543.

12. Fischer von Weikersthal G. Contramutan vertreibt den grippalen Infekt. Ärztliche Prax. 2000;11:19.

13. Directive 2001/83/EC of the European Parliament and of the Council of 6 November 2001 on the Community code relating to medicinal products for human use, as amended, OJ L311,28.11.2001, p. 67 .
14. Nauert C, Eckert C. Fixe Kombination aus Thymian-Fluidextrakt und Primelwurzel-Fluidextrakt zur oralen Therapie von Kleinkindern und Kindern mit Husten und Bronchialkatarrh. ZPhytother. 2003;24:130.

15. Atemwegsinfekte SK. Phytokombinatin lindert Beschwerden rasch und effizient. Naturamed. 2003;18(3):34-7.

16. Grünwald J, Graubaum HJ, Busch R, et al. Thymian und Primelwurzel - ein starkes Doppel gegen akute Bronchitiden. ZPhytother. 2006;27:214-20.

17. Nauert C, Grünwald J. Wirksamkeit und Verträglichkeit flüssiger Darreichungsformen einerfixen Kombination von Thymian und Primula bei Kindern mit akuter Bronchitis. Kongress Phytopharmaka Phytotherapie Berlin. 2005:31.

18. Nauert C, Grünwald J, Graubaum HJ. Behandlung von 839 Kindern und Kleinkindern mit akuter Bronchitis: Therapieerfolge einer fixen Kombination aus Thymian und Primula. ZPhytother. 2006;27:S13.

19. Grünwald J, Graubaum HJ, Freund R. Anwendungsbeobachtungen zur Phytotherapie bei Kindern mit akuter Bronchitis. Päd2006;12:371-6.

20. Nauert C. Nicht interventionelle Studie zeigt Effizienz bei Säuglingen. Naturamed. 2008;1:18-21.

21. Nauert C, Bentley C. Compliance, Verträglichkeit und Wirkung einer fixen Kombination von Thymian und Primula $(\mathrm{T}+\mathrm{P})$ bei 200 Säuglingen mit akuter Bronchitis. Z Phytother. 2008;29:S14.

22. Bentley C, Grünwald J. Behandlung von 300 Säuglingen, Kleinkindern und Kindern mit akutem grippalen Infekt: Therapieerfolge einer fixen Wirkstoffkombinatin (Contramutan). ZPhytother. 2006;S1:19.

23. Kelber O. Anwendungsbeobachtungen und retrospektive Studien bei Kindern. ZPhytother. 2010;31:40-7.

24. Gundermann K, Vinson B, Hänicke S. Die funktionelle Dyspepsie bei Kindern - eine retrospektive Studie mit einem Phytopharmakon. Päd 2004;10:408:10.

25. Vinson B, Radke M. Das pflanzliche Therapeutikum STW 5 zur Behandlung von funktionellen gastrointsetinalen Erkrankungen bei Kindern von 3-14 Jahren - eine prospektive nicht interventionelle Studie. Z Gastroenterol. 2009;47:917.

26. Eckert M. Pädiatrie: Homöopathisches Kombinationspräparat lindert Husten unterschiedlicher Genese. Naturamed. 2004;19(9):28-34.

27. Fasse M, Zieseniß E, Bässler D. Trockener Reizhusten bei Kindern - eine Anwendungsbeobachtung mit EibischSirup. Päd2005;11:3-8.

28. Bässler D. Erfahrungsbericht Phytohustil Hustenreizstiller Sirup bei Kindern bis 12 Jahren. Forschungsbericht. Darmstadt: Steigerwald Arzneimittelwerk; 2005.

29. Fasse M, Bässler D, Zieseniß E. Behandlung akuter Erkältungskrankheiten bei Kindern - Ergebnisse einer Anwendungsbeobachtung mit einem Primel-Thymian-Präparat. Päd 2006;12:3-8. 